\title{
COMPARATIVE STUDY OF STUDENTS' PERFORMANCE IN CONVENTIONAL AND OPEN DISTANCE EDUCATION PROGRAMMES IN NIGERIA
}

\author{
HOSEA ABALAKA APEH
}

Department of Counselling \& Educational Psychology, University of Abuja, Nigeria. FATI BINTA SHUAIBU

Department of Educational Foundations, Nassarawa State University, Keffi, Nigeria.

\begin{abstract}
This study was carried out to discern the relative effectiveness of open distance instruction delivery mode as compared to conventional (face-to-face) instruction delivery mode by understudying the academic performance of students enrolled in the University of Abuja, (a dual-mode university in Nigeria) from 20042008. Using the descriptive survey research method, students' academic performance records for four academic sessions were collected and analyzed using mean scores, standard deviations and t-test statistical analysis technique. The findings indicate that there were significant differences between the academic performance of students in conventional education and open distance education delivery modes. Students of conventional education programmes appear to perform better than their open distance education counterparts. This was contrary to many researches on distance education which indicated a finding of no significant difference between the two delivery modes. The findings can be explained by the way and manner in which the open distance programmes are run in Nigeria, which have perennially fallen short of internationally acceptable standards especially as it pertains to use of technology in open distance education. The paper recommends improvement in the distance learning as practiced in Nigeria, in order to harness the known comparative advantage of this delivery mode, for improving access to higher education by bridging the instructor-learner gap via modern information and communications technology.
\end{abstract}

\section{Introduction}

There is evidence of significant government resolve to provide education for all Nigerians. This resolve has been captured in the National Policy on Education where one of the objectives include "the provision of equal access to educational opportunities for all citizens of the country at the primary, secondary and tertiary levels both inside and outside the formal school system" (NPE, 2004:2). This objective encourages the provision of equal educational opportunities to all citizens at different levels of education in line with the understanding that education is a major key to human development and progress.

There are contradictory reports of population figures in Nigeria- One Hundred and Forty Million, Four Hundred and Thirty One Thousand and Seven Hundred and Ninety (140,431,790 (National Population Commission, 2006); 162,471,000 (United Nations est. July 2011) and170,123,740 (CIA World Factbook July 2012 est.) respectively. However, there can be no doubt when it comes to the fact that the population of Nigerians is on the increase. According to the 2012 revision of the World Population Prospects the total population was 159708000 in 2010, compared to only 37860000 in 1950.

Unfortunately, the increase in human population in Nigeria has left indelible marks on the entire polity especially in terms of demands for services that can better the lot of the people. Apparently, matching provision of services with the increased population has remained elusive. Education as a sector, no doubt, is one of the worse hit as a result of the lack of capacity to meet the growing demand for educational opportunity. 
Generally, the history of the Nigerian Educational system has been largely characterized by a continuous, steady decline over the years with the university system showing considerable decline in quality and quantity whether in enrolment figures or in academic programs offered. The facilities for teaching/learning, research and development have never kept pace with the increased demands arising from large student enrolment numbers impacting negatively on the quality of education provided for citizens. Today, the number of qualified candidates seeking opportunity for university education in Nigeria is on the rise (see Table 1), yet there is no corresponding increase in both quantity and quality of institutions providing the services.

Table 1: Annual Applicants and number admitted into higher education programmes in Nigeria between $2004 / 2005$ to $2007 / 2008$

\begin{tabular}{llllll}
\hline YEAR & $\begin{array}{l}\text { No. of } \\
\text { Universities }\end{array}$ & $\begin{array}{l}\text { No. } \\
\text { Applicants }\end{array}$ & $\begin{array}{l}\text { No. } \\
\text { Admitted }\end{array}$ & $\begin{array}{l}\% \\
\text { Admitted }\end{array}$ & $\begin{array}{l}\text { Left } \\
\text { Over }\end{array}$ \\
\hline $2004 / 05$ & 56 & 841,878 & 122,492 & $14.5 \%$ & 719,386 \\
$2005 / 06$ & 75 & 916,371 & N/A & N/A & N/A \\
$2006 / 07$ & 76 & 803,472 & 123,626 & $15.4 \%$ & 679,846 \\
$2007 / 08$ & 95 & $1,054,053$ & 200,000 & $19 \%$ & 854,053 \\
\hline
\end{tabular}

Source: Joint Admissions and Matriculation Board, 2008

This dwindling percentage of students admitted into higher education is largely because most universities lack the facilities and financial capacity be it physical or in terms of academic staff to accommodate students. Conventional or traditional university education therefore has been slow in responding to the challenges of the exponential growth in the number of those seeking admission. In spite of sincere government intentions, providing educational opportunity for a higher percentage of the population has remained an insurmountable mountain for most developing nations like Nigeria. Jegede (2000) attributed this to the preponderance of high population growth rate and low per capita income.

This trend has led researchers and planners of higher education to explore alternative strategy like open distance education, to improve access to higher education. UNESCO (2002:20) has stated that:

In efforts to meet the new and changing demands for education and training, open and distance learning may be seen as an approach that is at least complementary and under certain circumstances, an appropriate substitute for the face-to-face methods that still dominate most educational systems. While its benefits can be evaluated by technical, social and economic criteria, distance learning methods also have their own pedagogical merit, leading to different ways of conceiving knowledge generation and acquisition.

The UNESCO definition of open learning and distance education implies approaches to learning that focus on freeing learners from constraints of time and place while offering flexible learning opportunities. For many students, open and distance learning (ODL) is a way of combining work and family responsibilities with educational opportunities. Open 
Distance Education therefore can be seen as the kind of learning that is structured in such a way that the student and instructor are separated in time and place.

Open Distance Education in Nigeria is practiced in three forms namely: Outreach, Dualmode and Dedicated distance education institutions. The Dual-mode system, which is the focus of this present study, has been described by Ojo \& Olakulehin (2006) as the integration of distance learning system into face-to-face teaching and learning system. Dual-mode institutions, which have become typical of Nigerian Universities, have their origin in Australia and Canada where institutions integrate conventional and distance programmes.

Agboola (2000) cited Nigerian examples of dual-mode institutions as Universities of Abuja and Lagos. He further stated that, in practice, some other institutions in Nigeria operate distance teaching units created as an attachment to the faculty, school or institute of education or as outreach centres. Both Universities have a centre for distance education that is an integral part of the administrative structure of their respective Universities even though operating with a reasonable degree of autonomy.

Students' academic performance represents an objective measure of students' learning after a period of teaching operationalised as the overall cumulative mark of students at a particular time during the course of the programme. According to Unal (2005), learning outcomes is a statement of what a student is expected to know, understand and able to do at the end of a period of learning and how that learning is to be demonstrated. Redd (1998) has also said that quality and overall effectiveness of educational experiences are measured by student outcomes, student retention, attrition, and graduation rates. This underscores the relevance of use of academic performance of students in the two modes of instruction as basis for comparison.

\section{Statement of the Problem}

Open Distance education in Nigeria is negatively perceived. There is the opinion by some people that distance education is lower in quality than conventional education. Others perceive it as a mere opportunity for the adults (last chance seekers) to obtain a degree, therefore, it must not be for young people at all. Dede (1996) argues that despite the rapid growth in the popularity of distance learning, the quality of higher learning in Distance Education has been called to question.

There is a general apathy towards distance education in Nigerian with many people having the opinion that it is only a second best option. According to UNESCO (2001), there had always been a strong bias towards formal education of the conventional type in Nigeria and a general apathy towards distance education. Agboola (1997) indicates that, "by 1991/92 session, only about 22,000 students enrolled in University Distance Learning Units representing only $12.2 \%$ of enrolment in Nigerian Universities.

Although some previous studies conclude that there is no significant difference in the academic performance of students from the two modes of study, the apathy towards open distance learning continues leaving ODL as the second best option. This is a possible pointer to the fact that much research information is not available regarding the effectiveness of open distance education. This is why the researchers in this study felt that there is an urgent need to assess the relative effectiveness of distance education and 
conventional education delivery methods to help ensure that public perception as well as government policy decision takes their roots in accurate and adequate research information.

\section{Significance of the Study}

Distance education with its advantages such as time and cost convenience seem to be a viable alternative for providing educational opportunities to all. Society can therefore harness the advantages of distance education system to solve the problem of access to higher education; meet the needs of the full-time worker who is reluctant to leave their job for full time higher education; opportunity for homemakers who need flexibility in course schedules; valid provision for on-the-job training; reduced financial involvement for both students and the government as well as create opportunity for lifelong learning.

This study is made even more expedient in the face of the Federal Government's resolve to promote open learning system not only at the tertiary level but also in Polytechnics and Secondary schools through the Universal Basic Education programme as a vehicle for realizing Education-for-All. Knowledge of effectiveness of instruction or otherwise in this delivery mode can serve as basis for such recommendations therefore ensuring that government policy is rooted in research.

\section{Theoretical Framework}

Many researchers hold the opinion that distance education research has been carried on for too long without a research framework. According to Gunawardena and McIsaac (1996), without a strong base in research and theory, Distance Education has struggled for recognition by the traditional academic community. Phipps and Merisotis (1999) assert that there is a growing realization of the vital need to develop a more integrated, coherent and sophisticated program of research on distance learning.

Nouwens and Robinson (1991) suggest a complimentary framework, action-evaluation for evaluating educational programmes. Action research is a pluralist research approach that is based on the assumption that, when studying complex human activity systems, the mere recording of events and formulation of explanations by an uninvolved researcher is inadequate in and of itself. Conversely, action research proposes that those who have previously been designated as "subjects" should participate directly in research processes. Therefore, action research is more than the traditional interpretative research in the sense that the researcher is directly involved in the research setting and in the experience itself. The present study therefore is guided, in part, by hermeneutic assumptions in the sense that it sought to examine 'reality' from the actual academic achievement of the students enrolled in the programmes themselves.

\section{Review of Previous Studies}

Many studies on the effectiveness of distance education have concluded that distance education courses are as effective as traditional face-to-face (Clark, 2001; Saba, 2000; Phipps \& Merisotis, 1999). Russell (1999) is seen as the most comprehensive comparative research literature in Distance Education where he had a collection of 355 "no significant difference" studies ranging from 1928 to 1998 and covering all academic levels and delivery media types from correspondence to Web-based courses. Russell's 
work intended to support Richard Clark's (1983) original claim that a delivery medium contributes little if anything to the outcomes of planned instructions. In other words, that distance can be no better than traditional classroom instruction. Russell (1999) research is obviously the most frequently cited and also most criticized study in the literature on distance education. Russell (1999) asserted that no matter what kinds of media were involved distance education was as effective as traditional face-to-face instruction.

On the other hand, some recent studies have reported higher achievement in distance education than traditional classroom instruction (Shachar and Neumann 2003; Bernard et al., 2002). Furthermore, certain studies also showed evidence of a more positive trend of student achievement in distance education settings than in traditional face-to-face settings over time (Machtmes\& Asher, 2000; Zhao et al., 2004). Shachar and Neumann's (2003) research compared students' final grades in distance education with those in traditional classes. Their meta-analysis of 86 studies between 1990 and 2002 resulted in an overall effect size of 0.37 . They concluded that the overall effect size was a significant difference adopting their alternative hypothesis, "The final academic performance grades of students enrolled in distance education programs are higher than those enrolled in traditional faceto-face programs".

However, Ikerionwu (2004) in a survey study, using final degree classification of students in which where the researcher compared CGPA of students of two teacher education programmes of the University of Abuja was quite different. He found out that distance learning students performed worse than the conventional students in a study of two programmes of the University of Abuja. This result is quite different from all others, and therefore, requires confirmation through further research.

\section{Research Questions}

The principal question raised in this study is "What is the academic performance of students of conventional education mode and those in distance learning mode of the University of Abuja'? It is also hypothesized that 'There is no significant difference between the academic performance of students from conventional education and distance education delivery mode.'

\section{Method}

This study utilized the descriptive survey research design in a case study of a dual-mode institution, University of Abuja. According to Awotunde \& Ugodulunwa (2004), the concern of descriptive research is not why the observed distribution exist but what the distribution is.

\section{Population and Sample of Study}

The student population for this study included all fourth year students of the dual-mode university under study (University of Abuja) who were enrolled for programmes that were obtained in the two components of the University at the time of the study. Using purposive sampling technique, 4034 students were used for the study based on available records. Purposive sampling according to Patton (1990) is popular in qualitative research and refers to sampling where subjects are selected because of some characteristics. In this 
study, the programmes selected were those offered in both modes of study and courses taught were assessed by the same parameter.

\section{Instrumentation}

The instrument used for collecting data for this study was the Students' Academic Record which is based on the assessment of students' academic performances involving the compilation of students' continuous assessment and the student achievement in the endof-semester examinations. The Student's academic records (final degree clearance) were collected for the analysis. The items were known to be reliable as the examinations were usually moderated by professionals before they were administered.

\section{Data Collection and Analysis}

The data was collected personally by the researchers with the support of staff of the Academic Office of the University of Abuja. The data were analyzed using both descriptive and inferential statistics.

\section{Results}

\section{Analysis of Research Question}

What is the academic performance of students of conventional education mode and those in distance learning mode of the University of Abuja?

The descriptive statistics which included the means and standard deviations of the academic performances are shown in the Table 1 below.

Table 1: $\quad$ Descriptive Statistics for Students' Academic Performances

\begin{tabular}{lllllllllll}
\hline Year & \multicolumn{4}{c}{ Conventional Education Students } & \multicolumn{7}{c}{ Distance Education Students } \\
\cline { 2 - 11 } & N & Min. & Max. & Mean & SD & N & Min. & Max. & Mean & SD \\
\hline $2004 / 2005$ & 501 & 0.16 & 4.40 & 2.33 & 0.75 & 306 & 0.69 & 4.12 & 2.43 & 0.55 \\
$2005 / 2006$ & 505 & 0.42 & 4.16 & 2.23 & 0.69 & 565 & 0.21 & 3.58 & 2.27 & 0.53 \\
$2006 / 2007$ & 401 & 0.41 & 4.19 & 2.41 & 0.74 & 547 & 0.44 & 3.93 & 2.12 & 0.65 \\
$2007 / 2008$ & 704 & 0.65 & 4.57 & 2.33 & 0.74 & 505 & 0.27 & 4.18 & 2.05 & 0.66 \\
$2004-2008$ & 2111 & 0.16 & 4.57 & 2.32 & 0.73 & 1923 & 0.21 & 4.18 & 2.19 & 0.62 \\
\hline
\end{tabular}

The result in Table 1 presents scores on students' academic performance (final CGPA) of conventional and distance education students for four sessions as well as the total academic performance for the entire period under study (2004-2008). In 2004/05 session, mean score on students' academic performance is 2.33 and 2.43 for conventional and open distance education students respectively showing higher academic performance among the distance education students. In 2005/06 session, the mean score on students' academic performance was 2.23 and 2.27 for conventional and open distance education students respectively showing again higher academic performance among the distance education students. Next is the academic performance for the 2006/2007 academic year. The result shows students' academic performance to be 2.41 and 2.12 for conventional and open distance education students respectively showing in this case lower academic performance among the distance education students. In 2007/08 session, the result shows mean students' academic performance to be 2.33 and 2.05 for conventional and open 
distance education students respectively showing in this case lower academic performance among the distance education students.

Over all academic performance for the period under survey indicated that mean score was 2.32 for conventional education students while for distance education students, the mean score for the period under study was 2.19. This is an indication that the academic performance of conventional education students (2.32) was better than that of the open distance education component (2.19) of the University of Abuja between 2004-2008.

\section{Testing of Hypothesis}

There was no significant difference between the academic performance of students from conventional education and distance education delivery mode.

$\mathrm{t}$-Test analyses was used to test for the hypothesis and the result is shown on Table 2.

Table 2: t-Test Results on Difference between Academic Performance of Students from Conventional Education and Distance Education Delivery Mode

\begin{tabular}{llllllll}
\hline Mode of Study & Number & Mean & S.D. & df & t-value & Sig(2-tailed) & Decision \\
\hline Conventional & 2111 & 2.31 & .715 & 4032 & 6.789 & .000 & Rejected \\
Open Distance & 1923 & 2.10 & .657 & & & & \\
\hline
\end{tabular}

The test on Table 3 was carried out to determine possible difference in the academic performance of students enrolled in the two mode of study. A significant value of .000 (less than the 0.05 level of significance) shows that there is significant difference. The hypothesis is therefore rejected. This implies that there is significant difference between conventional education and open distance education students with reference to their academic performance.

\section{Discussion of Findings}

This study found significant difference in academic performance between conventional education students and distance learning students. It has been clearly established that, students enrolled in conventional (face-to-face) programme indicated better academic performance than those enrolled in the distance learning programme from the year 2004 to 2008. This is an unexpected result judging from the myriads of studies in distance education that found "No Significant Difference" in academic performance between the two groups. A summary of comparative research literature of distance education by Russell (1999) who reviewed a collection of 355 (and counting) 'no significant difference' studies showed that there is no significant difference in students' learning outcome. Russell (1999) thus declared that a delivery medium contributes little if anything to the outcome of planned instruction- in other words, that distance can be no better than conventional instruction.

Having said that, it is important to report however that Ikeriounwu (2004) compared final degree classification for students of two teacher-education programmes of the University of Abuja and found that distance learning students performed worse than the conventional education students. The consistency between the findings of this present study and 
Ikeriounwu (2004) brought to the fore, the obvious need to assess open distance education programmes as currently implemented in Nigeria.

Furthermore, Arbaugh (2004) and Diaz (2002) also suggested that open distance education at the least had a neutral effect on academic performance and at the best have a positive effect on academic performance. Shachar \& Neumann (2003) in a study based on 86 studies and using learning outcome data found data from 15,000 participating students, the result of the meta-analysis shows a strong positive trend indicating that distance learning is an effective form of instruction. The study even found that students engaged in distance education academically outperform their face-to-face counterparts.

\section{Factors/Reasons}

The significant comparative difference observed in this study between conventional and distance education students could be due to a number of reasons. First, the learning environment of the distance learning schools where primary and secondary schools play the host for weekend contacts amidst crowded lectures can be very unpleasant. Second, the unavailability of study materials as at and when due; large classes with adults squeezing themselves into seats constructed for kids can also constitute a major force towards the low level course satisfaction among distance learning students.

The findings made in this study therefore was an indictment of distance education practices in its present form in Nigeria. Coming at the time that around the world, nations are taking advantage of the development in information and communications technology (ICT) to provide higher education for their citizens, using distance learning strategy, is a wake-up call. More so, there was a growing acceptance of distance learning systems as the pedagogy of the future. As observed by UNESCO (2002), "in efforts to meet the new and changing demands for education and training, open and distance learning may be seen as an approach that is at least complimentary and under certain circumstances, an appropriate substitute for the face-to-face methods that still dominates most educational systems." Distance education therefore offers glaring advantages that could be harnessed for the purpose providing access to quality education if there is compliance with best practices.

Also fundamental to achieving remarkable success through distance learning strategy is the use of instructional media to bridge the gap between instructor and learner. This is no doubt a missing component in the scenario under which distance learning is practiced in Nigeria. Largely, a developmental consideration, the absence of advanced information and communications technology which serve the purpose of ensuring maximum interaction between learners and instructors has remain the Achilles hills of attempts at exploring open and distance education option for instruction.

There is no argument that the secret of the success recorded by some institutions running open distance programmes is purely in their effort to improve on learner-instructor interaction as well as learner-learner interaction. Apeh (2010) has clearly argued that improvement in open distant education offerings can be achieved through use of modern information and communications technology. Schools running such programmes in Nigeria and indeed the University of Abuja which is under review here must show evidence of departure from the archaic form of running ODE schools where three contacts and distribution of poor quality study materials are considered sufficient. 


\section{Conclusion and Recommendations}

Conventional Education in Nigeria is not meeting current and increasing demand for higher education by the citizens. Seeking alternative means of providing education to many who are in need is therefore an imperative that cannot be overlooked. Distance Education presents an opportunity but is bedeviled with negative perceptions and doubts as to its comparative effectiveness when compared to the conventional education delivery method. The finding of this study reechoes this sentiments and calls for serious review of distance education as practiced in Nigeria.

Having realized the relevance of open distance education as a panacea to the problem of access to higher education in Nigeria and in line with the belief that distance education may be the alternative to providing higher education opportunity for many Nigerian who desire it, there is every reason to improve on the quality of open distance education offerings in Nigeria. More so that many people may not be disposed to the idea of leaving their current job for fulltime university education.

It is therefore recommended that contact between instructor and learner as well as among learners should be improved via use of ICT resources as this has been found to improve course delivery and, in effect, academic performance of learners hence, overall effectiveness of the open distance education programmes in Nigeria. Evidence from advanced nations where no significant difference between instruction deliveries using these two modes have been found reinforces this position. Adoption of modern technological techniques as media of instruction in distance learning programmes rather than the almost archaic print medium remains an issue that cannot be neglected. Interactive media can help narrow the gap created by the absence of the instructor on a face-to- face basis.

There is also urgent need for review of the distance learning programmes to enhance its effectiveness by taking a look at the human resources available. The case where teaching staff employed for the conventional education programmes doubles as the teaching workforce for the open distance programme may overload the lecturers and reduce their efficiency. When Part-time lecturers are continually used to teach Part-time students, the knowledge impacted may remain perpetually part-time knowledge resulting in half-baked graduates.

This researcher also calls for an evolution of a distance learning model that is sensitive to the peculiarity of the Nigeria learning environment. Imported models must be subjected to modifications within our peculiar cultural context to ensure relevance.

\section{References}

Agboola, B.A. (2000). Strategies for motivating the part-time tutor for enhanced programme and job satisfaction. In Agboola (Ed) Research studies on teacher education by distance learning. Suleja: Joson-Sam Modern publication.

Agboola, B. A. (1997). "Dreams and Realities of Student Support Services in Distance Education: An African University Experience" ABSU Journal of Distance Education.3 (1): $184-192$. 
Apeh, H. A. (2010). A comparative study of students' course satisfaction and academic performance in conventional and distance programmes in University of Abuja. Unpublished PhD Thesis, University of Abuja, Abuja, Nigeria.

Arbaugh, J. B. (2004). Learning to learn online: A study of perceptual changes between multiple online course experiences. Internet and Higher Education, 7: 169-182.

Awotunde, P.O. \& Ugodulunwa, C.A. (2004). Research methods in education. Jos: Fab Anieh (Nig) Ltd.

Bernard, R. M.; Lou, U. \& Abrami, P.C. (2002).Comparing distance education and traditional instruction: an "in-progress" meta-analysis of the empirical literature. www.unb.ca/naweb/proceedings/2002/p02Bemard.html

CIA (2012). The world factbook.https://www.cia.gov/library/publications/the-worldfactbook/http://en.wikipedia.org/wiki/Demographics_of_Nigeria

Clark, R. E. (1983). Reconsidering Research on Learning from Media. Review of Educational Research, 53 (4): 445-459.

Clark, T. (2001). Virtual school: status and trends. Phoenix, AZ: West Ed/Distance Learning Resource Network. Retrieved June 1, 2003, from http://www.wested.org/online_pubs/virtualschools.pdf

Diaz, D. (2002). Online drop rates revisited. Retrieved August 11, 2005 from University of North Carolina, The Technology Source Archives Web site: http://ts.mivu.org/default.asp?show=article $\&$ id=981

Dede, C. (1996). Emerging technologies and distributed learning. American Journal of Distance Education, 10 (2): 4-36.

Gunawardener, C.L. and McIsaac, M.S. (1996). Distance education. In D. Jonassen (ed.). Handbook of Research for Educational Communications and Technology (pp. 403437) - New York: Simon and Schuster Macmillan.

Ikeriounwu, J.C. (2004). Comparative analysis of University of Abuja final degree classification of conventional and distance learning students. Nigerian Journal of Open and Distance Education (NJODE), 1(1): Joyce Graphic Printer and Publisher.

Jegede, O. J. (2000). Evolving a national policy on distance education: an agenda for implementation. Education Today, 8 (3): 14-9.

Matchmes, K. and Asher, J.W. (2000). A meta-analysis of the effectiveness of Tele courses in distance education. The American Journal of Distance Education. 14 (1): $27-46$.

National Policy on Education (2004). Federal Ministry of Education, Abuja, Nigeria. 
Nouwens, F. and Robinson, P. (1991). Evaluation and the development of quality learning materials. Australian Journal of Educational Technology, 7 (2): 93-116. http://www.ascilite.org.au/ajet/ajet7/nouwens.html

NPC (2006). http://www.population.gov.ng/

Ojo, O.D.; Ogdan, R. \& Olakulelun, F. K. (2006). Cost effectiveness of open and distance learning in Nigeria. Responses from focus group discussions in Online Journal of Distance Learning Administration. No. ix No. II summer 2006.

Patton, M. Q. (1990). Qualitative evaluation and research methods (2nd ed.). Newbury Park, A: Sage Publications.

Phipps, R., \& Merisotis, J. (1999). What's the difference? A review of contemporary research on the effectiveness of distance learning in higher education. Washington DC: Institute for Higher Education Policy, for the American Federation of Teachers \& National Education Association. Retrieved on September 12, 2003, from http://www.ihep.com/Pubs/PDF/Difference.pdf

Russell, T.L. (1999). The no significant difference phenomenon. Chapel Hill, NC: Office of Instructional Telecommunications, North Carolina State University.

Redd, K. E. (1998). Historically black colleges and universities: Making a comeback. New Directions for Higher Education (pp. 33-43). San Francisco: Jossey-Bass.

Saba, F. (2000). Research in distance education: A status report. International Review of Research in Open and Distance Learning, 1(1).

Shachar, M. \& Neumann, Y. (2003). Differences between traditional and distance education academic performance: A meta-analytic approach. International Review of research in Open and Distance Learning. 4 (2).

Unal Zafer, (2005). Comparing the learning outcomes and course satisfaction of webbased vs. classroom-based instruction. Unpublished doctoral dissertation submitted to the Florida State University College of Education.

UNESCO (2001). Distance education in the E-9 countries. Graph Print: France.

UNESCO (2002). Open and distance learning: trends, policy and strategy consideration, Paris.

United Nations (2012). World population prospects: the 2012 revision: New York: Population Division, Department of Economics and Social Affairs, United Nations.

Zhao, Y.; Lei, J.; Yan, B. \& Tan, S. (2004). What makes the difference? A practical analysis of research on the effectiveness of distance education. Available online at http://ott.educ.msu.edu/literature/report.pdf 